\title{
До питання оцінювання впливу системи попередження про надзвичайні ситуації на потенційно-небезпечних об’єктах на спроможності військ (сил)
}

\author{
Євген Левіщенко * А \\ А Воєнно-наукове управління Генерального штабу Збройних Сил України, пр-кт Повітрофлотський, 28, м. Київ, 03049, Україна
}

Received: October 12, 2020 | Revised: October 27, 2020 | Accepted: October 31, 2020

DOI: $10.33445 /$ sds.2020.10.5.14

\begin{abstract}
Анотація
В статті досліджуються питання оцінювання впливу системи попередження про надзвичайні ситуації на потенційно-небезпечних об'єктах на спроможності військ (сил). Ефективне застосування військ (сил) в умовах виникнення надзвичайних ситуацій на потенційно-небезпечних об'єктах можливе тільки у разі обладнання місць розташування (базування) відповідними системами попередження. Ефективність системи попередження може бути оцінена ймовірнісним показником здатності даної системи виконувати покладені на неї завдання попередження військ (сил) про надзвичайні ситуації на потенційно-небезпечних об'єктах. Оцінювання ефективності системи попередження запропоновано здійснити відповідним показником, який залежить від імовірності сприйняття особовим складом сигналу попередження та ймовірності адекватної реакції особового складу на сигнал попередження.
\end{abstract}

Ключові слова: попередження, спроможності, надзвичайні ситуації, війська.

\section{Постановка проблеми}

Необхідність ведення Збройними Силами України операцій (бойових дій) на території із значною кількістю потенційно-небезпечних об'єктів (ПНО) вимагають чіткої організації заходів щодо попередження військ (сил) про надзвичайні ситуації на даних об'єктах $[1,2]$. Для вироблення обгрунтованих рекомендацій щодо збереження необхідного рівня спроможностей військ (сил) в умовах виникнення надзвичайних ситуацій на ПНО важливу роль відіграє наявність відповідного методичного підходу для оцінювання впливу системи попередження військ на спроможності військ (сил), що і обумовлює актуальність даної статті.

\section{Аналіз останніх досліджень та публікацій}

Окремі питання оцінювання спроможностей військ (сил) в умовах виникнення надзвичайних ситуацій на Пно розглядаються в роботах [2-4]. Проте, оцінювання впливу системи попередження військ (сил) про надзвичайні ситуації на ПНО на спроможності військ (сил) у вказаних роботах розкривається тільки в організаційній площині, в більшості випадків приймається, що сигнали попередження доводяться своєчасно та дозволяють особовому складу провести відповідні заходи захисту. Тому, метою статті $€$ викладення можливих підходів оцінювання впливу системи попередження про надзвичайні ситуації на ПНО на спроможності військ (сил).

\footnotetext{
* Здобувач, начальник відділу, e-mail: lev1753@ukr.net, ORCID: 0000-0001-8166-0577
} 


\section{Виклад основного матеріалу}

Ефективне застосування військ (сил) в умовах виникнення надзвичайних ситуацій на ПнО можливе тільки у разі обладнання місць розташування (базування) відповідними системами попередження. Зазначені системи являють собою комплекс технічних засобів та організаційних заходів, за допомогою якого забезпечується повідомлення особового складу, які перебувають у місцях розташування (базування), про виникнення надзвичайної ситуації, а також управління заходами захисту.

Улаштування таких систем попередження передбачає виконання комплексу робіт, пов'язаних з вибором типу, характеристик елементів системи попередження, а також монтажем та введенням їх в експлуатацію.

Водночас, як свідчить практика, змонтовані на сьогодні системи попередження не завжди забезпечують виконання покладених на них завдань [5]. Причиною такого стану $\epsilon$ те, що оцінювання ефективності функціонування системи попередження військ (сил) про надзвичайні ситуації на ПнО як на стадії ії проєктування, так і під час їі експлуатації, не проводиться.

3 метою підвищення спроможностей військ (сил) в умовах виникнення надзвичайних ситуацій на ПНО пропонується уточнити алгоритм діями щодо оптимізації вибору параметрів системи попередження.
Основною серед цих дій $\epsilon$ проведення розрахунку показника ефективності функціонування даної системи, на підставі якого здійснюватиметься уточнення переліку необхідного обладнання для ії побудови.

Ефективність системи попередження може бути оцінена ймовірнісним показником здатності даної системи виконувати покладені на неї завдання попередження військ (сил) про надзвичайні ситуації на $\Pi \mathrm{HO}-k_{E c}$.

Значення показника $k_{E c}$ ефективності функціонування системи попередження військ (сил) про надзвичайні ситуації на ПНО може бути розраховано на підставі розгляду можливих сценаріїв подій при подачі відповідного сигналу попередження про надзвичайну ситуацію.

3 цією метою за аналогією з [6] доцільно використати метод логічних дерев подій (мал.). Як видно 3 малюнку, результатом ефективного функціонування системи попередження військ (сил) про надзвичайні ситуації на ПНО є настання події “війська (сили) зберігають необхідні спроможності в виникнення надзвичайної ситуації на Пно". При цьому даній події має передувати сенсорне сприйняття сигналу попередження про надзвичайну ситуацію на ПНО, а також адекватна реакція особового складу на сприйнятий сигнал.

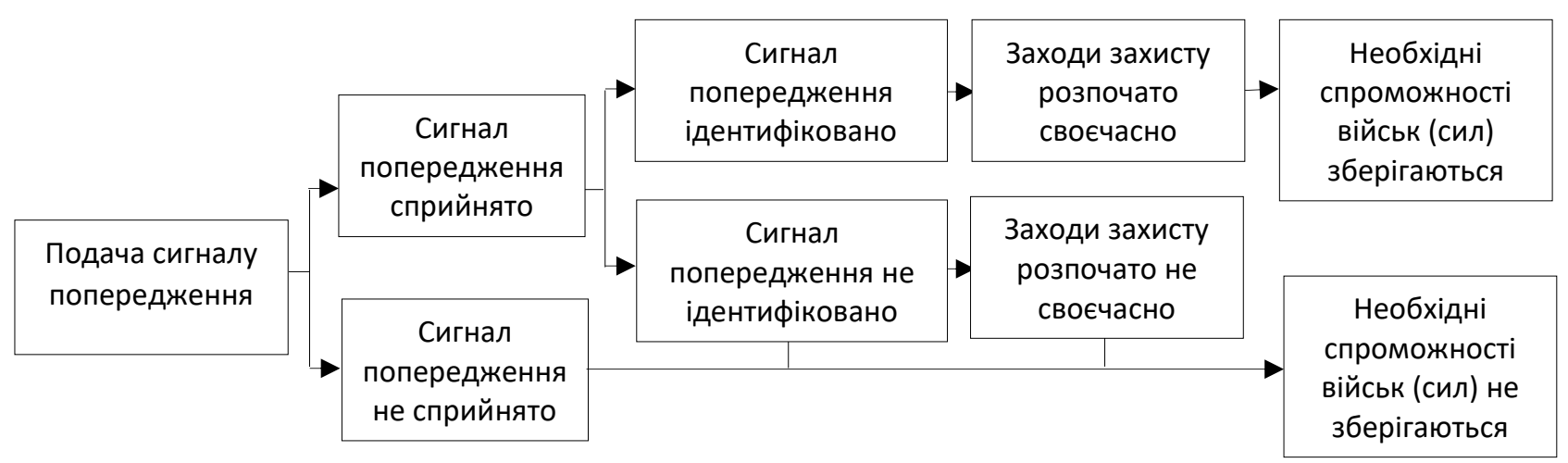

Малюнок - Дерево подій при попередженні військ (сил) про надзвичайну ситуацію на ПНО

3 урахуванням цього показник ефективності функціонування системи попередження військ (сил) про надзвичайні ситуації на ПНО KEc може бути визначено за формулою:

$$
K_{e c}=P_{c \Pi} P_{\text {вud }}
$$


де $P_{c п}-$ імовірність сприйняття особовим складом сигналу попередження;

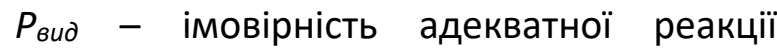
особового складу на сигнал попередження.

Значення імовірностей сприйнятяя особовим складом сигналу попередження в залежності від способу подачі сигналу системою попередження та адекватної реакції особового складу на сигнал попередження на підставі експериментальних даних [7, 8] наведено в табл. $1,2$.

Таблиця 1 - Значення ймовірності сприйняття особовим складом сигналу попередження $P_{c п}$ в залежності від способу подачі сигналу

\begin{tabular}{|c|c|}
\hline Спосіб подачі сигналу & $\begin{array}{c}\text { Значення } P_{c п} \text { В залежності від способу подачі } \\
\text { сигналу }\end{array}$ \\
\hline Звуковий & 0,975 \\
\hline Світловий & 0,4 \\
\hline $\begin{array}{lll}\text { Комбінований (поєднання } & \text { світлового } \\
\text { звукового способів) } & \end{array}$ & 0,987 \\
\hline
\end{tabular}

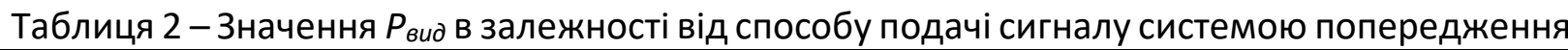

\begin{tabular}{|c|c|c|c|}
\hline \multirow[t]{2}{*}{$\begin{array}{c}\text { Інформативність } \\
\text { сигналу }\end{array}$} & \multirow[t]{2}{*}{$\begin{array}{c}\text { Варіанти подачі сигналу } \\
\text { попередження }\end{array}$} & \multicolumn{2}{|c|}{$\begin{array}{c}\text { Значення ймовірності адекватної реакції } \\
\text { особового складу на сигнал попередження } \\
\text { Рвид для ступенів підготовленості } \\
\text { особового складу }\end{array}$} \\
\hline & & підготовлений & непідготовлений \\
\hline Низька & $\begin{array}{c}\text { Сирена, мерехтлива } \\
\text { лампочка }\end{array}$ & 0,37 & 0,09 \\
\hline $\begin{array}{c}\text { Середня } \\
\text { (з інформацією про } \\
\text { подію) }\end{array}$ & $\begin{array}{c}\text { Сирена, доведення } \\
\text { сигналу попередження } \\
\text { голосом, світлове табло з } \\
\text { сигналами попередження }\end{array}$ & 0,56 & 0,228 \\
\hline $\begin{array}{c}\text { Середня } \\
\text { (з інформацією про } \\
\text { подію та необхідні дії) }\end{array}$ & $\begin{array}{c}\text { Сирена, доведення } \\
\text { сигналу попередження } \\
\text { голосом да діями по них, } \\
\text { світлове табло з } \\
\text { сигналами попередження }\end{array}$ & 0,577 & 0,181 \\
\hline $\begin{array}{c}\text { Достатня } \\
\text { (з інформацією про } \\
\text { подію та необхідні дії) }\end{array}$ & $\begin{array}{c}\text { Сирена, доведення } \\
\text { сигналу попередження } \\
\text { голосом, світлове табло з } \\
\text { сигналами попередження } \\
\text { та діями по них } \\
\end{array}$ & 0,833 & 0,761 \\
\hline
\end{tabular}

Показник стану збереження спроможностей військ (сил) в умовах виникнення надзвичайної ситуації на ПНО ( $\alpha 7)$ з урахуванням показника ефективності функціонування системи попередження військ (сил) про надзвичайні ситуації на ПНО буде визначатися за формулою:

$$
\alpha_{7}=C_{\mathrm{B}(0)} k_{\mathrm{Ec}},
$$

де $C_{8(0)}$ - потенційні спроможності відповідного угруповання військ (сил);
$C_{8(c)}-$ спроможності відповідного угруповання військ (сил) в умовах функціонування того чи іншого варіанту СМПВНС на ПНО;

$k_{E c}$ - коефіцієнт ефективності системи попередження про надзвичайну ситуацію на ПНО.

Результати функціонування традиційної системи попередження військ (сил) про надзвичайну ситуацію на ПнО свідчать [5], що подача сигналів попередження здійснюється 
у більшості випадків за допомогою звукових сирен C-28, C-40 з варіантом доведення сигналу попередження голосом да діями по них, також використовується світлове табло 3 сигналами попередження. Коефіцієнт ефективності традиційної системи попередження про надзвичайну ситуацію на ПНО складає $k_{E c}-0,56$.

Для підвищення ефективності функціонування традиційної системи попередження про надзвичайну ситуацію на ПнО пропонується: використовувати комбінований спосіб подачі сигналу про надзвичайну ситуацію на ПНО (поєднання світлового та звукового способів); дообладнати місця розташування (базування) особового складу світловими табло з сигналами попередження та діями по них.

Результати функціонування традиційної та перспективної системи попередження військ (сил) про надзвичайну ситуацію на ПНО наведено в табл. 3.

Таблиця 3 - Результати функціонування існуючої та перспективної системи попередження військ (сил) про надзвичайну ситуацію на ПНО

\begin{tabular}{|c|c|c|c|c|}
\hline $\begin{array}{c}\text { Спосіб подачі } \\
\text { сигналу }\end{array}$ & $\begin{array}{c}\text { Імовірність } \\
\text { сприйняття } \\
\text { особовим } \\
\text { складом } \\
\text { сигналу } \\
\text { попередження } \\
P_{с п} \\
\end{array}$ & $\begin{array}{c}\text { Інформативність } \\
\text { сигналу }\end{array}$ & $\begin{array}{c}\text { Варіанти подачі } \\
\text { сигналу оповіщення }\end{array}$ & $\begin{array}{c}\text { Значення } \\
\text { ймовірності } \\
\text { адекватної реакції } \\
\text { особового складу } \\
\text { на сигнал } \\
\text { попередження } \\
P_{\text {вид }} \\
\end{array}$ \\
\hline \multicolumn{5}{|c|}{ Традиційна система } \\
\hline Звуковий & $P_{c \pi}-0,987$ & $\begin{array}{c}\text { Середня } \\
\text { (з інформацією } \\
\text { про подію та } \\
\text { необхідні дії) }\end{array}$ & $\begin{array}{c}\text { Сирена, доведення } \\
\text { сигналу } \\
\text { попередження } \\
\text { голосом да діями по } \\
\text { них, світлове табло з } \\
\text { сигналами } \\
\text { попередження }\end{array}$ & $\begin{array}{c}\text { Особовий склад } \\
\text { підготовлений } \\
P_{\text {вид }}-0,577\end{array}$ \\
\hline \multicolumn{5}{|c|}{ Перспективна система } \\
\hline $\begin{array}{c}\text { Комбінований } \\
\text { (поєднання } \\
\text { світлового та } \\
\text { звукового } \\
\text { способів) }\end{array}$ & 0,987 & $\begin{array}{c}\text { Достатня } \\
\text { (з інформацією } \\
\text { про подію та } \\
\text { необхідні дії) }\end{array}$ & $\begin{array}{c}\text { Сирена, доведення } \\
\text { сигналу } \\
\text { попередження } \\
\text { голосом, світлове } \\
\text { табло з сигналами } \\
\text { попередження та } \\
\text { діями по них }\end{array}$ & $\begin{array}{c}\text { Особовий склад } \\
\text { підготовлений } \\
P_{\text {вид }}-0,833\end{array}$ \\
\hline
\end{tabular}

За умови впровадження перспективних способів та засобів коефіцієнт ефективності системи попередження про надзвичайну ситуацію на ПНО буде складати $k_{E c}-0,82$. Для прикладу, при прийнятому значенню потенційних спроможностей відповідного угруповання військ (сил) $C_{8(о)}-0,78$, спроможності угруповання військ (сил) в умовах функціонування традиційної системи попередження будуть складати $C_{8(0) \text { iсн }}-0,56$, а в умовах функціонування перспективної

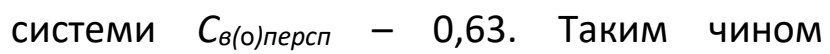
реалізація запропонованих рекомендацій призводить до збільшення ефективності функціонування системи попередження військ (сил) про надзвичайну ситуацію на ПНО на $12 \%$. 


\title{
Висновки
}

В статті викладені можливі підходи оцінювання впливу системи попередження про надзвичайні ситуації на ПНО на спроможності військ (сил). Оцінювання ефективності системи попередження запропоновано здійснити відповідним показником, який залежить від імовірності

сприйняття особовим складом сигналу попередження та ймовірності адекватної реакції особового складу на сигнал попередження. Напрямом подальших досліджень $\epsilon$ розроблення моделі попередження військ (сил) для різних варіантів організації взаємодії.

\section{Список використаних джерел}

1. Дузь-Крятченко О.П. Основи стратегії національної безпеки та оборони держави : підручник / О.П. Дузь-Кряіченко, Ю.В., Руснак І.С, Пунда, В. ІІ. Грищенко, ІІ.М. Грицай, В.М. Гудим, Ю.Г. Даник, В.І. Єфіменко та ін.; за заг. ред. В.М. Телелима. - 3-є вид., перероб. і доп. Київ : НУОУ ім. Івана Черняховського, 2015. 620 с.

2. Стрижевський В. В., Музиченко Д. П. Надзвичайні ситуації природного та техногенного характеру. Участь формувань сухопутних військ збройних сил України у ліквідації наслідків надзвичайних ситуації природного та техногенного характеру: навч. посіб. Київ: НАОУ, 2007. 58 с.

3. Методика роботи командирів і штабів, форми бойових документів із забезпечення РХБ захисту: навч. посіб. / Л. Ф. Кузьменко, О. В. Хіврич, О. В. Джежулей та ін./ Під ред. Р. М. Факадея - Київ : НАОУ, 2002. 172 c.

4. Блекот О. М., Бондаренко О. В., Джежулей О. В., Ковальов О. С. Методика оцінки обстановки при надзвичайних ситуаціях після зруйнувань (аварій) на потенційно небезпечних об'єктах: навч. посіб. Київ: HAOY, 2007. 40 c.
5. Михайлова А. В. Система моніторингу та попередження про надзвичайні ситуації в зоні проведення операції об'єднаних сил: дис.канд.тех.наук: 21.02.03. Київ, 2020. $236 \mathrm{c.}$

6. Лиходід Р. В., Рудницький В. М. Метод оцінювання систем оповіщення людей про пожежу, що базується на показниках ефективності їх застосування. Збірник наукових праць Харківського університету Повітряних Сил, 2015. Вип. 2(43). C. 129-132.

7. Лыходид Р. В., Рудницкий В. Н. Исследование зависимости эффективности систем оповещения о пожаре от способности людей адекватно реагировать на сигналы оповещения. Системи обробки інформації: Збірник наукових праць. Харків: Харківський університет Повітряних Сил імені І. Кожедуба, 2014. Вип. 2 (118). С. 276281.

8. Інженерне обладнання будинків і споруд. Проектування електрообладнання об'єктів цивільного призначення: ДБН В.2.5-232010 Офіц. вид. Київ : ДП “Укрархбудінформ", 2010. 20 с.

\section{К вопросу оценки воздействия системы предупреждения о чрезвычайных ситуациях на потенциально опасных объектах на способности войск (сил)}

\author{
Евгений Левищенко * А \\ *Corresponding author: Соискатель ученой степени, e-mail: lev1753@ukr.net, ORCID: 0000-0001-8166-0577 \\ А Военно-научное управление Генерального штаба Вооруженных Сил Украины, пр-кт Воздухофлотский, 28, г. Киев, 03049, Украина
}

\section{Аннотация}

В статье исследуются вопросы оценки влияния системы предупреждения о чрезвычайных ситуациях на потенциально опасных объектах на способности войск (сил). Эффективное 
применение войск (сил) в условиях возникновения чрезвычайных ситуаций на потенциально опасных объектах возможно только в случае оборудования мест расположения (базирования) соответствующими системами предупреждения. Эффективность системы предупреждения может быть оценена вероятностным показателем способности данной системы выполнять возложенные на нее задачи предупреждения войск (сил) о чрезвычайных ситуациях на потенциально опасных объектах. Оценка эффективности системы предупреждения предложено осуществить соответствующим показателем, который зависит от вероятности восприятия личным составом сигнала предупреждения и вероятности адекватной реакции личного состава на сигнал.

Ключевые слова: предупреждения, способности, чрезвычайные ситуации, войска.

\title{
On the question of assessing the impact warning system for emergencies potentially dangerous objects on the ability of troops (forces)
}

\author{
Evgen Levischenko * A \\ *Corresponding author: PhD student, e-mail: lev1753@ukr.net, ORCID: 0000-0001-8166-0577 \\ A Military Scientific Department of the General Staff of the Armed Forces of Ukraine, 28, Povitroflotskyi Ave, Kyiv, 03049, Ukraine
}

\begin{abstract}
The article examines the issues of assessing the impact of the emergency warning system on potentially dangerous objects on the capabilities of troops (forces). Effective use of troops (forces) in emergencies at potentially dangerous sites is possible only if the location (base) is equipped with appropriate warning systems. The effectiveness of a warning system can be assessed by a probabilistic indicator of the ability of this system to perform its tasks of warning troops (forces) about emergencies at potentially dangerous objects. It is proposed to evaluate the effectiveness of the warning system with an appropriate indicator, which depends on the probability of perception by the personnel of the warning signal and the probability of adequate response of the personnel to the warning signal.
\end{abstract}

Keywords: warnings, capabilities, emergencies, troops.

\section{References}

1. Duz-Kryatchenko O. P. Fundamentals of national security strategy and state defense: textbook / O. П. Duz-Kryaichenko, Yu. V., Rusnak I. S., Punda, V. V. and others; for general ed. V.M. Telelima. - 3rd ed., Revised. and ext. Kyiv: NUOU, 2015. 620 p.

2. Stryzhevsky V. V., Muzychenko D. P. Emergencies of natural and man-made nature. Participation of formations of land troops of the Armed Forces of Ukraine in liquidation of consequences of emergencies of natural and technogenic character: textbook. way. Kyiv: NAOU, 2007. 58 p.

3. Methods of work of commanders and staffs, forms of combat documents to ensure RHB protection: textbook. way. / L. F. Kuzmenko, O. V. Khivrych, O. V. Dzhezhuley and others / Ed. R. M. Fakadeya. Kyiv: NAOU, 2002. 172 p. 4. Blekot O. M., Bondarenko O. V., Dzhezhuley O. V., Kovalev O. S. Methods of assessing the situation in emergencies after destruction (accidents) at potentially dangerous objects: textbook. way. Kyiv: NAOU, 2007. 40 p. [in Ukraine]

5. Mikhailova A. V. Monitoring and warning system for emergencies in the area of the joint forces operation: Candidate of Technical Sciences: 21.02.03. Kyiv, 2020. 236 p. [in Ukraine]

6. Lykhodid R. V., Rudnytsky V. M. Method of 
evaluation of fire alarm systems based on the indicators of their effectiveness. Collection of scientific works of Kharkiv University of the Air Force, 2015. Issue. 2 (43). Pp. 129-132.

7. Lykhodid R. V., Rudnitsky V. N. Investigation of the dependence of the efficiency of fire alarm systems on the ability of people to adequately respond to alarm signals.
Information processing systems: Collection of scientific works. Kharkiv: I. Kozhedub Kharkiv University of the Air Force, 2014. Issue. 2 (118). Pp. 276-281.

8. Engineering equipment of buildings and structures. Design of electrical equipment for civil purposes: DBN B.2.5-23-2010 Ofits. kind. Kyiv: SE “Ukrarkhbudinform”, 2010. 20 p. 